\title{
Micro-Catchment Techniques: An Effective Water Conservation Practice in Mango
}

\author{
Syed Mazar Ali", Kamala Bai, B.G. Hanumantharaya and K.H. Nagraj \\ Subject Matter Specialist (Agriculture Engineering), KrishiVigyan, Kendra, \\ Ramanagara, Karnataka-562120, India \\ *Corresponding author
}

\begin{tabular}{|c|c|}
\hline & ABSTRACT \\
\hline & \multirow{7}{*}{$\begin{array}{l}\text { Dryland horticulture constitutes major part in horticulture crop production. Moisture stress } \\
\text { is one of the major limiting factor in production of mango in dryland horticulture, since the } \\
\text { rainfall is highly erratic and it is not possible to utilize available rainwater efficiently. } \\
\text { Mango is one of the major crop grown in Ramanagara district covering an area of } 22172 \\
\text { ha. Due to poor soil and water conservation practices in mango moisture retention is low in } \\
\text { the soil that affects productivity. In this context, front line demonstration on Micro- } \\
\text { catchment techniques was conducted in the mango grower's field in an area of } 6 \text { ha. Micro- } \\
\text { catchment techniques means development of small structures across land slope which } \\
\text { captures surface runoff and stores in plant zone for subsequent plant use. Micro-catchment } \\
\text { techniques including half-moon, V-shaped, and diamond shaped bunds were constructed } \\
\text { across each mango plant. Further vetivera grass was planted over the catchment bund to } \\
\text { control erosion. Highest average mean fruit yield/tree was recorded in half-moon water } \\
\text { harvesting system and is significantly superior to other water harvesting system and } \\
\text { minimum was in control plots. The fruit yield was increased by } 22.2 \% \text { in compare with } \\
\text { control and B:C ratio was found to be } 2.9 \text {. The demonstrated area received annual average } \\
\text { rainfall of } 21.8 m m \text { which conserves } 1101 \text { trs of water per catchment. Several educational } \\
\text { programmes were conducted to popularize Micro-catchment techniques. }\end{array}$} \\
\hline & \\
\hline $\begin{array}{l}\text { Micro-catchment, } \\
\text { Yield, }\end{array}$ & \\
\hline & \\
\hline Article Info & \\
\hline $\begin{array}{l}\text { Accepted: } \\
16 \text { April } 2017 \\
\text { Available Online: } \\
10 \text { May } 2017\end{array}$ & \\
\hline & \\
\hline
\end{tabular}

\section{Introduction}

Mango is one of the major crops grown in the Ramanagara district covering 22172ha of Area. Major challenge in the district is low and erratic rainfall which makes agriculture a risky enterprise. Moisture stress is one of the major limiting factors in production of mango in dryland horticulture, since the rainfall is highly erratic and it is not possible to utilize available rainwater efficiently. Rainwater harvesting can help in supplying enough water to improve crop yield. According to Handi et al., (2003) water resources will steadily decline because of population growth, pollution and expected climate change due to the problem of global warming. Hence, the water crisis is getting more attention among all countries specially the developing ones. Therefore, new strategies and techniques dealing with water problems are highly needed. Micro-catchment is one of the direct water harvesting system where small structures are constructed across land slopes which captures surface runoff and stores in plant zone for subsequent plant use. 
Generally this system involves controlled concentration of surface runoff from catchment into a smaller lower-lying cropped area (Boers et al., 1982). Micro catchment systems provide many advantages over other irrigation schemes. They are simple and inexpensive to construct and can be built rapidly using local materials and manpower. Effective moisture conservation practice also includes various types of Mulching material. Goode and Hyryoz (1968) and Lal (1976) reported that mulches increase the soil and water content under intermittent rain or irrigation. Keeping all these point of view a front line demonstration was conducted in Farmers field with the objective includes, to Demonstrate Various Micro catchment techniques. To strengthen bunds using Vegetative measures. And also to study Growth and Yield parameters in Mango

\section{Materials and Methods}

The experiment was conducted during 201314 in 10 number of farmer field covering 100 mango plants (aged 7-10 year) to the area of 2.5 ha in different villages of Ramanagara district. Micro-catchment structures are delineated based on spacing of crop. The demonstration plot is having Red soil with poor drainage facility

\section{Types of Catchment/bund}

Four type of catchment basin/Treatment was demonstrated in farmer's field. Selection of Catchment was done based on slope of the land. Before the execution of experiment, the trees basins were ploughed with spade to keep them weed-free.

T1-Semi-circular/Half-moon Bund T2-Square shaped/ Circular catchment T3-V-Type bund T4-Controll
Mango plants with no catchment are taken as control for study

Half-moon or Semi-circular bunds were created at downstream side of plant across the slope having $30 \mathrm{~cm}$ width and $30 \mathrm{~cm}$ height at a radius of $2.5 \mathrm{~m}$ away from tree trunk for storage of surface runoff water collected from catchment. Similarly circular bunds were created at no slope, with $30 \mathrm{~cm}$ height, $30 \mathrm{~cm}$ width and at radius of $2.5 \mathrm{~m}$ away from tree trunk and V-type of bund were created across the slope having $30 \mathrm{~cm}$ height, $30 \mathrm{~cm}$ width with $5 \mathrm{~m}$ length and width from tree trunk.

\section{Vegetative Measures for Soil and water conservation}

\section{Vetiver grass}

Micro-catchment bund are more susceptible to erosion from rain, in order to strengthen the bund, Vetiver grass (Vetiveria Zizanioides) also called as 'Khus' is planted for all the treatments with the plant to plant spacing of $20 \mathrm{~cm}$

\section{Water Harvesting}

Water harvesting is defined as collection of runoff from catchment area. Water harvesting is technology to increase food security in drought prone areas. Erosion control and recharge of ground water are additional advantages of water harvesting techniques. Microcatchment is direct method of harvesting where water is stored in root zone of each plant for its subsequent use. The ground slope is a key limiting factor to water harvesting. Water harvesting is not recommended for areas where slopes are greater than $5 \%$ due to uneven distribution of run-off and large quantities of earthwork required which is not economical. 
Rainfall pattern over the period of 2 years was studied for calculating water harvested in each catchment and results were drawn according to FAO-56 research paper on Irrigation and drainage (Table.1)

\section{Recording growth and yield parameters}

Bio-metric parameters such as No. of fruit set / inflorescence, No. of flowers / Inflorescence, No. of Shoots/branch were recorded by random sampling (Table.2). Fruit was harvested at maturity and yield per tree is recorded. Chlorophyll content was measured using SPAD meter and is expressed in number. The data was statistically analysed using RCBD (Randomized complete block diagram) and level of significance used at $5 \%$.

In order to promote the technology by large scale, various extension activities, Viz., Oncampus training, Off-campus training, Publication, and News coverage was given (Table 3)

\section{Results and Discussion}

Vegetative growth of Mango plant was influenced by Micro-catchment techniques under rainfed condition as shown in Table.2.Maximum average Number of inflorescence/branch, No of flowers/inflorescence, No of fruit set/ inflorescence, Chlorophyll content and Fruit yield $(\mathrm{Kg} /$ tree $)$ was found in Half-moon /semi-circular catchment with vetiver grass and shows significance difference with other techniques. This may be due to influence of stored runoff water at plant zone, thus retaining moisture for long time. The results are inconformity with the findings of Patil and Swamy (2003). Additionally if the catchment surface is lined with suitable mulch material improves plant growth Sharma et al. (1986).Vetivera grass used as lining material improves structure of bund apart from controlling soil from erosion.

Table.1 Rainfall Distribution pattern and Water Harvesting

\begin{tabular}{|l|l|l|l|l|}
\hline Year & Month & $\begin{array}{l}\text { Rainfall } \\
\text { (Madbal rain } \\
\text { gauge) in mm }\end{array}$ & $\begin{array}{l}\text { Effective } \\
\text { rainfall } \\
(\mathrm{mm} / \mathrm{month})\end{array}$ & $\begin{array}{l}\text { *Water } \\
\text { collected in } \\
5 \mathrm{~m}^{2} \text { area }\end{array}$ \\
\hline 2013 & July & 17.0 & 0 & 0 \\
\hline & August & 92.4 & 47 & 215 \\
\hline & September & 125.8 & 71 & 245 \\
\hline & October & 61.8 & 26 & 170 \\
\hline & November & 21.8 & 8 & 110 \\
\hline & December & 3.8 & 0 & 0 \\
\hline 2014 & July & 29.8 & 8 & 110 \\
\hline & August & 144.6 & 87 & 265 \\
\hline & September & 197.8 & 127 & 315 \\
\hline & October & 178.6 & 111 & 295 \\
\hline & November & 25.5 & 8 & 110 \\
\hline & December & - & - & - \\
\hline
\end{tabular}

* As per FAO-56 Research paper on Irrigation and Drainage for Red soil under Semi-Arid condition 
Table.2 Yield and Growth parameters of Mango

\begin{tabular}{|l|c|c|c|c|c|}
\hline Treatments & $\begin{array}{c}\text { No. } \\
\text { inflorescence } \\
\text { /branch }\end{array}$ & $\begin{array}{c}\text { No of flowers/ } \\
\text { inflorescence }\end{array}$ & $\begin{array}{c}\text { No of fruit } \\
\text { set/ } \\
\text { inflorescence }\end{array}$ & Chlorophyll & $\begin{array}{c}\text { Fruit } \\
\text { yield } \\
\text { (Kg/tree) }\end{array}$ \\
\hline $\begin{array}{l}\text { T1- Half- } \\
\text { moon }\end{array}$ & 4.6 & 2980.7 & 5.1 & 65.6 & 55.5 \\
\hline T2- Circle & 3.9 & 2795.5 & 4.0 & 60.4 & 50.3 \\
\hline T3- V-bund & 4.4 & 2852.2 & 4.6 & 63.9 & 53.0 \\
\hline T4- control & 10.4 & 1750.7 & 2.2 & 44.8 & 45.4 \\
\hline Cd & 0.71 & 255.7 & 0.75 & 6.72 & 3.4 \\
\hline SEM & 0.24 & 88.13 & 0.26 & 2.31 & 1.2 \\
\hline
\end{tabular}

Table.3 Extension activities conducted to the farmers

\begin{tabular}{|c|c|}
\hline Activity & $\begin{array}{l}2013- \\
14\end{array}$ \\
\hline On-Campus training programmes & 1 \\
\hline Off-Campus training programmes & 4 \\
\hline Demonstrations & 15 \\
\hline Group discussions & 10 \\
\hline Radio talk & 1 \\
\hline Publications & 2 \\
\hline Total & 33 \\
\hline
\end{tabular}

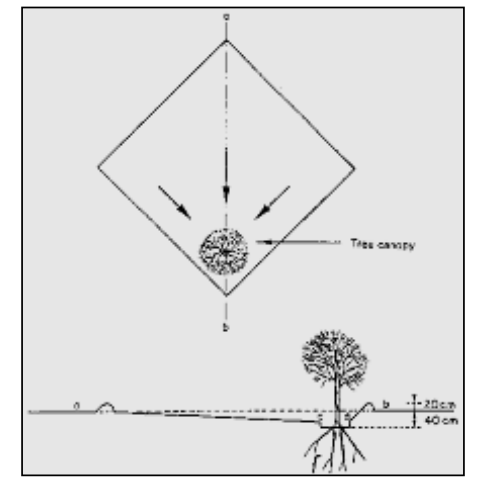

Square Type Catchment

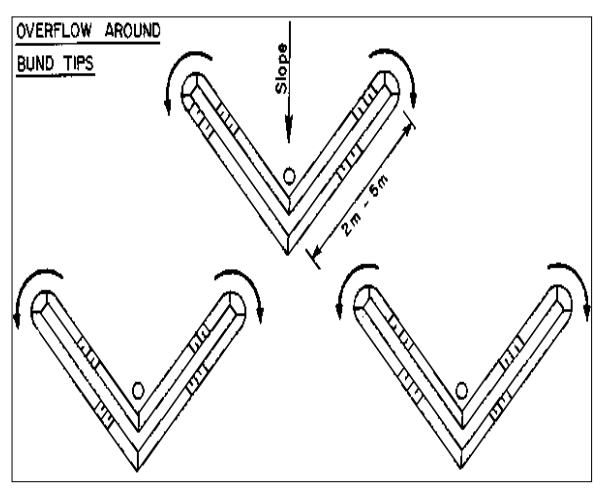

V- Type Catchment

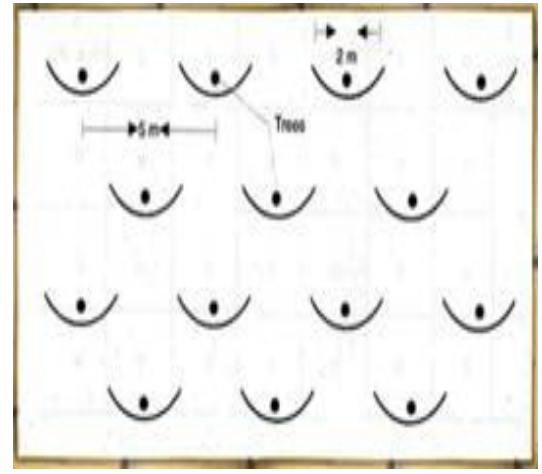

Semi-circular catchment

\section{Fruit yield}

Fruit yield and its contributing characters as influenced by rain water harvesting techniques in apple (Table 2). Highest average mean fruit yield and projected yield per hectare were recorded in full moon water harvesting system and significantly superior to other water harvesting system and minimum was in control plots Fruit yield and its contributing characters as influenced by rain water harvesting techniques in apple (Table 2). Highest average mean fruit yield and projected yield per hectare were recorded in full moon water harvesting system and significantly superior to other water harvesting system and minimum was in control plots Fruit yield and its contributing 
characters as influenced by rain water harvesting techniques in apple (Table 2). Highest average mean fruit yield and projected yield per hectare were recorded in full moon water harvesting system and significantly superior to other water harvesting system and minimum was in control plots Fruit yield is influenced by rain water harvesting techniques in Mango (Table 2). Highest average mean fruit yield/tree was recorded in half-moon water harvesting system and is significantly superior to other water harvesting system and minimum was in control plots. The fruit yield was increased by $22.2 \%$ in compare with control. Popularization of the technology through extension activities helps farmers in adopting large scale.

\section{Implications}

The water conservation technology in arid and Semi-arid regions is an old yet an effective way of establishment and subsequent growth of trees. There are several methods prevalent indifferent parts of the world, which basically are based on the principle of a donor area and a collector area. In such a system a major portion of the land (donor area) remains unutilized. In the present time, when increasing pressure on land necessitates that more and more area be put to use, an integrated system of water harvesting for tree plantation needs special attention. This is especially useful if the trees are to be planted in an agroforestry system.

In conclusion, half-moon /semi-circular catchment with vetiver grass proves to be better water harvesting technique in Mango plantation in compare with other water harvesting techniques which maintains better soil moisture thus improving fruit yield. These techniques are especially useful in agro forestry system.

\section{References}

Boers, T.M., Ben Asher, J., 1982. A review of rain water harvesting. Agric. Water Manage. 5, 145 \pm 158 .

FAO, 2006. FAO Irrigation and Drainage paper on Crop evopotranspiration. Food and Agriculture Organization of the United Nations, Rome, Italy. Paper No. 56.

Goode, J.E. And Hyryoz, K.J., 1968, The response of malling jewel and malling exploit rasp berries to different soil moisture conditions and straw mulching. Journal of Horticulture Science, 45 (3): 379-391.

Handia, L, J, T, and Caroline $\mathrm{M}$. (2003).Potential of Rainwater Harvesting in Urban Zambia. Physics and Chemistry of the Earth, 28: 893896.

Patil, P.B. AndSwamy, G.K.S., 2003, Compendium of the Inter School on Advances in Production and Management of Rainfed Fruit Crops . MAU, Parabhani, pp. 11-14.

Sharma, K.D., Pareek, O.P., Singh, H.P., 1986. Micro-catchment water harvesting for raising jujube orchards inan arid climate.Trans. Am. Soc. Agric. Eng. 29(1), 112 \pm 118 .

\section{How to cite this article:}

Syed Mazar Ali, Kamala Bai, B.G. Hanumantharaya and Nagraj, K.H. 2017. Micro-Catchment Techniques: An Effective Water Conservation Practice in Mango. Int.J.Curr. Microbiol.App.Sci. 6(5): 2965-2969. doi: http://dx.doi.org/10.20546/ijcmas.2017.605.335 